\section{Total Synthesis of (+)-Alsmaphorazine C}

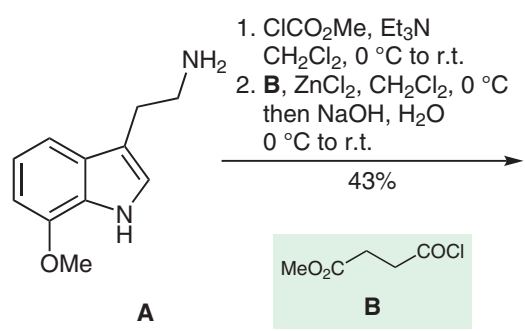

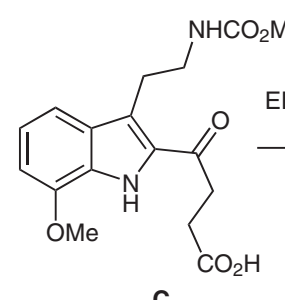

C

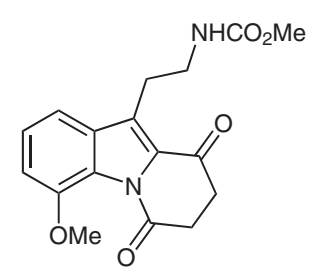

D
EDC•HCl, DMAP (5 mol\%) $\mathrm{CH}_{2} \mathrm{Cl}_{2}, 0^{\circ} \mathrm{C}$ to r.t.

Steglich esterification

$$
\text { E }(2 \mathrm{~mol} \%)
$$
THF $0^{-40}{ }^{\circ} \mathrm{C}$ Noyori asymmetric transfer hydrogenation

1. $\mathrm{AcOH}(10 \mathrm{~mol} \%), \mathrm{HCHO}$ $\mathrm{NaCNBH}_{3}, \mathrm{MeCN}, 0^{\circ} \mathrm{C}$ TPAP $(20 \mathrm{~mol} \%), 0{ }^{\circ} \mathrm{C}$ to r.t. 2. $\mathrm{NaBH}(\mathrm{OMe})_{3}, \mathrm{CH}_{2} \mathrm{Cl}_{2}, 0^{\circ} \mathrm{C} \mathrm{MeO}$ then $\mathrm{Et}_{3} \mathrm{~N}, \mathrm{TESCl}, 0^{\circ} \mathrm{C}$ to r.t then $\mathrm{K}_{2} \mathrm{CO}_{3}, \mathrm{MeOH}, 40^{\circ} \mathrm{C}$<smiles>COc1cccc2c(CCNC(C)=O)c3n(c12)C(=O)CC[C@H]3O</smiles>

\section{Category}

Synthesis of Natural

Products and

Potential Drugs

\section{Key words}

(+)-alsmaphorazine C

photo-Fries reaction

indole alkaloids

van Leusen reaction

continuous-flow

chemistry

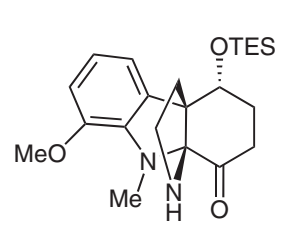
$92 \% \downarrow \mathrm{K}_{2} \mathrm{CO}_{3}, \mathrm{I}, \mathrm{MeCN}, 60^{\circ} \mathrm{C}$

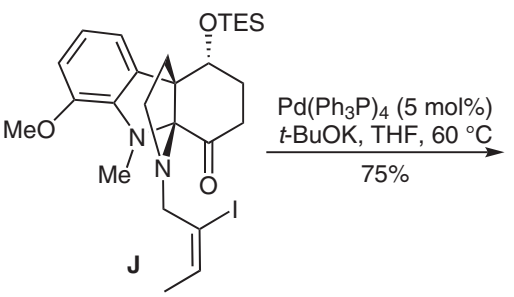
then 4 A $\mathrm{MS}, \mathrm{NMO}$ $63 \%$<smiles>C/C=C(/I)CBr</smiles>

$\mathbf{F}$

Significance: In 2012, Morita and co-workers isolated the indole alkaloid (+)-alsmaphorazine $\mathrm{C}$ from the leaves of Alstonia pneumatophore. Ding and coworkers present the first and asymmetric synthesis of this intriguing natural product.
Comment: Hydroxy ketone $\mathbf{F}$ was quickly accessed from tryptamine $\mathbf{A}$ in four steps. The key photoFries reaction/addition to imine cascade gave complex tetracycle $\mathbf{G}$ in $55 \%$ yield. Further elaboration of this intermediate gave the natural product in a total of 14 steps. 